\title{
Concentration of plasminogen activators and inhibitor in the human endometrium at different phases of the menstrual cycle
}

\author{
S. C. L. Koh, P. C. Wong, R. Yuen, S. E. Chua, B. L. Ng and \\ S. S. Ratnam \\ Department of Obstetrics and Gynaecology, National University of Singapore, National University \\ Hospital, Lower Kent Ridge Road, Singapore 0511
}

\begin{abstract}
Summary. The concentrations of tissue plasminogen activator (t-PA), urokinase plasminogen activator (u-PA) and plasminogen activator inhibitor (PAI-1) have been determined in endometrial curettings obtained from 46 subfertile women during proliferative, early or late secretory phases of the menstrual cycle. t-PA activity and antigen concentrations was significantly higher $(P<0.001)$ in late secretory endometrium than in proliferative or early secretory endometrium. Higher concentrations of PAI-1 antigen $(P<0.05)$ were also noted in late secretory phase than in proliferative and early secretory endometrium. However, u-PA concentration was not significantly different and no PAI activity could be demonstrated in the menstrual phases studied. Zymography studies confirmed the presence of both t-PA and u-PA in the endometrium. Ovarian hormonal patterns may therefore influence the activity of plasminogen activators especially of t-PA in the endometrium during various phases of the menstrual cycle.
\end{abstract}

Keywords: plasminogen activators; urokinase; plasminogen activator inhibitor; endometrium; human

\section{Introduction}

The plasminogen activators (PA) play an important role in biological processes involving cell migration, tissue degradation and remodelling (Martin \& Arias, 1982). It is suggested that the concentrations of PA in the endometrium are regulated by sex hormones (Mullins et al., 1980; Kneifel et al., 1982; Peltz et al., 1983). Oestrogen stimulates endometrial growth and synthesis or release of PA, whereas progesterone is involved in secretory changes reducing the concentration of PA by inhibiting the conversion of the proactivator or synthesis of PA or inhibiting both (Liedholm, 1975; Casslen \& Astedt, 1983a, b; Kjaelgaard et al., 1988). Two forms of PA, urokinase (u-PA) and tissue activator (t-PA), are reported to be present in the endometrial tissues and uterine fluids (Casslen \& Astedt, 1983a, b; Koh et al., 1988). However, the physiological role of these two forms of endometrial PA is not clear. They are immunologically different but both of them cleave plasminogen in the same way. t-PA is involved in thrombolysis, whereas u-PA is, among other functions, involved in the tissue degradation in normal as well as in pathological conditions including cancer (Astedt et al., 1981; Dano et al., 1985). PA may be released into the uterine cavity to remove fibrin deposits that might occur, and may aid in the migration of spermatozoa and implantation of the blastocyst (Casslen \& Astedt, 1981).

Wide variations in endometrial PA concentrations have been reported throughout the menstrual cycle (Koh et al., 1988). The present study was undertaken to investigate whether the hormonal changes during the menstrual cycle have any effects on the concentrations of t-PA, u-PA and PAI-1 in the endometrium. 


\section{Materials and Methods}

\section{Endometrium}

Endometrial curettings $(n=45)$ were obtained from 45 subfertile subjects. The subjects had been trying unsuccessfully for conception for more than 12 months and attending our Infertility Clinic for their routine infertility check-up. The age and menstrual patterns of the subjects are shown (Table 1). The subjects underwent routine laparoscopy, dilatation and curettage. Half of the curettings were immediately rinsed with cold $0.15 \mathrm{~mol} \mathrm{NaCl} 1^{-1}$ to remove blood, blotted dry, wrapped in parafilm and stored at $-70^{\circ} \mathrm{C}$ until homogenization. They were classified into either proliferative $(n=20)$, early $(n=12$, corresponding to day 14-18) or late $(n=14$, day $24-28$ of the menstrual cycle) secretory by histological dating.

Table 1. Age and menstrual patterns of subfertile subjects

\begin{tabular}{lcccc}
\hline & Age & \multicolumn{3}{c}{ Menstrual patterns } \\
& (years) & $(<21$ days) & $(21-35$ days) & (unknown) \\
\hline$n$ & 45 & 1 & 34 & 10 \\
Mean (sD) & $31 \cdot 9(3 \cdot 9)$ & 15 & $28 \cdot 4(1 \cdot 8)$ & - \\
Range & $(25-40)$ & 15 & $(23-33)$ & - \\
\hline
\end{tabular}

Although endometrial tissues used were from subfertile females, all of them were histologically normal and had normal menstrual patterns of $28 \pm 7$ days cycle.

\section{Homogenization}

After thawing, the endometrial tissues were weighed and then homogenized in $0.15 \mathrm{~mol} \mathrm{NaCl}$ I $^{-1}(100 \mathrm{mg}$ tissue in $\mathrm{I} \mathrm{ml}$ ) using an IKA Turrax homogenizer at $2-4^{\circ} \mathrm{C}$ for 3-4 min. The homogenate was spun at $27000 \mathrm{~g}$ in an ultracentrifuge $\left(4^{\circ} \mathrm{C}\right.$ for $\left.5 \mathrm{~min}\right)$ and the supernatant was divided in aliquots in plastic tubes and immediately stored at $-70^{\circ} \mathrm{C}$ until assayed.

\section{Determination of PA and PAI-1}

t-PA and PAI-1 activities were determined using the plasmin generation method described by Koh et al. $(1989 \mathrm{a}, \mathrm{b})$. The method used for determining the t-PA and PAI-1 activities in plasma was applied to biological fluids. Briefly, for t-PA assay one volume of endometrial extract was treated with two volumes of $0 \cdot 1 \mathrm{~mol} \mathrm{HCl} \mathrm{l}^{-1}$, and after $30 \mathrm{~min}$ incubation another two volumes of $0.1 \mathrm{~mol} \mathrm{NaOH}^{-1}$ was added and this acid-treated aliquot was used for assay. A protein solution of homogenized fibrin $\left(850 \mu \mathrm{g}\right.$ protein $\left.\mathrm{ml}^{-1}\right)$ was used as a stimulator in the presence of an excess of plasminogen and the plasmin generated by the t-PA present in the acid-treated sample was measured by the release of para-nitroanilide (pNA) from the chromogenic substrate S-2251 at $492 \mathrm{~nm}$. For the assay of PAI activity $50 \mu \mathrm{l}$ of $50 \mathrm{iu}$ single chain $\mathrm{t}-\mathrm{PA} \mathrm{ml} \mathrm{J}^{-1}$ was incubated with $50 \mu \mathrm{l}$ of endometrial extract for $10 \mathrm{~min}$ at room temperature. After incubation $0.9 \mathrm{ml}$ Tris buffer was added and the residual t-PA was measured by the t-PA activity assay described. The amount of t-PA remaining after incubation is inversely proportional to the concentration of inhibitor present. The antigen assays for t-PA, u-PA and PAI-1 were determined using ELISA kits purchased from American Diagnostics Inc. (New York, USA). The ELISA kits use a double-antibody principle for t-PA assay and mouse monoclonal antibodies for $\mathrm{u}-\mathrm{PA}$ and PAI-1 antigen assays. The activity and antigen concentrations are expressed per $100 \mathrm{mg}$ of wet endometrial tissue.

\section{t-PA, u-PA standards and rabbit antibodies}

Single chain melanoma cell t-PA 86/67 and two chain u-PA 66/46 were obtained from the National Institute for Biological Standards and Controls (NIBSC), Holly Hill, London. The standards were used for the t-PA and PAI activity assays and for raising antibodies in rabbits for characterization of PAs. Locally bred male rabbits were immunized with t-PA or u-PA, $400 \mathrm{iu}$, in complete Freund's adjuvant and boostered with the same units every two weeks until the antibody titre was constant. Bleeding was performed from the ear vein and the blood was taken to determine the serum antibody titre in a fibrin plate. Serial dilutions of the antibody were incubated with either t-PA or u-PA $\left(1.0 \mathrm{iu} \mathrm{m}^{-1}\right)$ for $30 \mathrm{~min}$ to determine the inhibition of lysis on the fibrin plate. The highest dilution that gave complete inhibition of lysis is the titre for the antibody. The antibody titre used in this study was 1:64 for t-PA and I:160 for u-PA. In zymography studies both antibodies gave specific lysis zones for either t-PA or the two chain u-PA markers. 


\section{Characterization of PA}

Sodium dodecyl sulfate polyacrylamide gel electrophoresis (SDS-PAGE) (Weber \& Osborn, 1969) was performed on stored unreduced endometrial extracts. Endometrial extracts $(20 \mu \mathrm{l})$ pre-mixed in solubilizing buffer were used together with single chain t-PA and two chain u-PA as markers. Electrophoresis was performed for $3 \mathrm{~h}$ at $35 \mathrm{~mA}$ with cooling. After SDS-PAGE, fibrin zymography of PAs was performed as described by Granelli-Piperno \& Reich (1978) and Koh et al. (1988). Briefly, the fibrin-agar gel was prepared by adding 1 caesin unit of plasminogen (Kabi, Sweden) to $12 \mathrm{ml}$ of $2.30 \mathrm{~g}$ human fibrinogen $1^{-1}$ (Kabi) containing $1.0 \%$ agarose (Induboise Agarose A37: Reactifs, IBF France). Bovine thrombin (Roche) was added, $50 \mathrm{ml}$ in 50 iu bovine thrombin $\mathrm{ml}^{-1}$, and the mixture was immediately transferred into a $10 \mathrm{~cm} \times 10 \mathrm{~cm}$ sandwiched glass plate with U-frame of $1.5 \mathrm{~mm}$ thickness to form a fibrin gel. After electrophoresis the gel was washed in $1 \%$ Triton X-100 for $1 \mathrm{~h}$, laid onto the fibrin agar gel and incubated in a humid environment at $37^{\circ} \mathrm{C}$ for about $18 \mathrm{~h}$. After incubation the fibrin-agar gel was washed in distilled water and stained with Coomassie blue. Fibrinolysis appeared as clear zones after staining.

\section{Statistical analysis}

Unpaired Student's $t$ test was used for calculation of statistical significance. A $P$ value of $\leqslant 0.05$ was regarded as statistically significant.

\section{Results}

Late secretory endometrium had significantly higher mean t-PA activity ( $16.4 \pm 12 \cdot 5 \mathrm{iu}$ in $100 \mathrm{mg})$, t-PA antigen $(24.7 \pm 16.1 \mathrm{ng}$ in $100 \mathrm{mg})$ and PAI- 1 antigen $(1.25 \pm 1.1 \mathrm{ng}$ in $100 \mathrm{mg})$ than either the proliferative or early secretory endometrium (Table 2 ). The proliferative endometrium had significantly raised $(P=0.01) \mathrm{t}-\mathrm{PA}$ antigen (mean $14.0 \pm 6.7 \mathrm{ng}$ in $100 \mathrm{mg}$ tissue) compared with the early secretory endometrium (mean $2.9 \pm 1.1 \mathrm{ng}$ in $100 \mathrm{mg}$ tissue). The mean t-PA activity of $4.8 \pm 4 \cdot 3 \mathrm{iu}$ in $100 \mathrm{mg}$ tissue in the proliferative phase was higher than the mean of $2.9 \pm 1.1 \mathrm{ng}$ in $100 \mathrm{mg}$ of tissue in the early secretory endometrium, but this was not statistically significant. PAI-1 activity could not be detected in all endometrial tissues studied, although low PAI-1 antigen was found in most of the tissues. PAI-1 antigen was significantly higher $(P<0.05)$ in late secretory endometrium (mean $1.25 \pm 1.07 \mathrm{ng}$ in $100 \mathrm{mg}$ ) than in proliferative (mean $0.52 \pm 0.77 \mathrm{ng}$ in $100 \mathrm{mg}$ ) and early secretory phase endometrium (mean $0.56 \pm 0.32 \mathrm{ng}$ in $100 \mathrm{mg}$ ) of tissue. No significant differences in PAI-1 antigen were found between proliferative and early secretory endometrium (Table 2).u-PA antigen concentrations ranged from 0 to $2.6 \mathrm{ng}$ in $100 \mathrm{mg}$ tissue, and were not statistically different in the three phases of the menstrual cycle although late secretory endometrium had a higher amount $(0.75 \pm 0.78 \mathrm{ng}$ in $100 \mathrm{mg})$ than proliferative $(0.37 \pm 0.79 \mathrm{ng}$ in $100 \mathrm{mg})$ and early secretory endometrium $(0.33 \pm 0.43 \mathrm{ng}$ in $100 \mathrm{mg}$ tissue). The distribution of t-PA, PAI- 1 antigen and u-PA in the endometrium at different phases of the menstrual cycle is shown (Figs 1 and 2).

\section{Characterization of PA}

Plasminogen-dependent fibrinolytic activity was seen in the endometrium in the regions corresponding to molecular masses of 31,54 and $67 \mathrm{kDa}$ (Fig. 3a). When anti-u-PA 1:100 was impregnated into the fibrin-agar gel, free t-PA of $67 \mathrm{kDa}$ molecular mass was seen (Fig. 3b) and one chain u-PA of $54 \mathrm{kDa}$ was observed in the endometrium on the addition of 1:50 anti-t-PA to the fibrin-agar gel (Fig. 3c).

\section{Discussion}

The plasminogen activators have been implicated in several reproductive processes including ovulation, trophoblast implantation, menstrual bleeding and mammary gland involution (Kneifel et al., 1982). All of these events share the common feature of tissue remodelling or cell migration, and most of them are under hormonal modulation. Both t-PA and u-PA are found in the 
Table 2. Activity and amounts of antigen of plasminogen activators and PAI-1 in $100 \mathrm{mg}$ endometrium from subfertile females at proliferative and late secretory phases of the menstrual cycle compared with early secretory endometrium

\begin{tabular}{|c|c|c|c|c|c|}
\hline & \multicolumn{2}{|c|}{ t-PA } & \multicolumn{2}{|c|}{ PAI-1 } & \multirow{2}{*}{$\begin{array}{c}\text { u-PA } \\
\mathrm{Ag}(\mathrm{ng})\end{array}$} \\
\hline & Act (IU) & $\mathrm{Ag}(\mathrm{ng})$ & Act (IU) & $\mathrm{Ag}(\mathrm{ng})$ & \\
\hline \multicolumn{6}{|c|}{ Proliferative } \\
\hline$n$ & 19 & 19 & 19 & 19 & 19 \\
\hline Mean & $4 \cdot 8$ & $14 \cdot 0$ & nd & 0.52 & $0 \cdot 37$ \\
\hline SD & $4 \cdot 3$ & 6.7 & - & 0.77 & $0 \cdot 68$ \\
\hline Range & $(0 \cdot 16-16 \cdot 9)$ & $(3 \cdot 6-27 \cdot 1)$ & & $(0-3 \cdot 5)$ & $(0-2 \cdot 3)$ \\
\hline$P$ & ns & 0.001 & & ns & ns \\
\hline \multicolumn{6}{|c|}{ Early secretory } \\
\hline$n$ & 12 & 12 & 12 & 12 & 12 \\
\hline Mean & $2 \cdot 9$ & $5 \cdot 4$ & nd & 0.56 & $0 \cdot 33$ \\
\hline SD & $1 \cdot 12$ & $3 \cdot 42$ & - & 0.32 & 0.43 \\
\hline $\begin{array}{l}\text { Range } \\
P\end{array}$ & $(1 \cdot 2-5 \cdot 4)$ & $(1 \cdot 0-12 \cdot 0)$ & & $(0 \cdot 16-1 \cdot 3)$ & $(0-1 \cdot 3)$ \\
\hline \multicolumn{6}{|c|}{ Late secretory } \\
\hline$n$ & 14 & 14 & 14 & 14 & 14 \\
\hline Mean & $16 \cdot 4$ & $24 \cdot 7$ & nd & $1 \cdot 25$ & 0.75 \\
\hline SD & $12 \cdot 48$ & $16 \cdot 13$ & - & $1 \cdot 07$ & 0.62 \\
\hline Range & $(1 \cdot 88-50 \cdot 0)$ & $(4 \cdot 4-56 \cdot 0)$ & & $(0 \cdot 25-3 \cdot 89)$ & $(0-2 \cdot 6)$ \\
\hline$P$ & 0.001 & $<0.001$ & & $<0.05$ & ns \\
\hline
\end{tabular}

Act: activity; Ag: amount of antigen; ns: not significant; nd: not detected

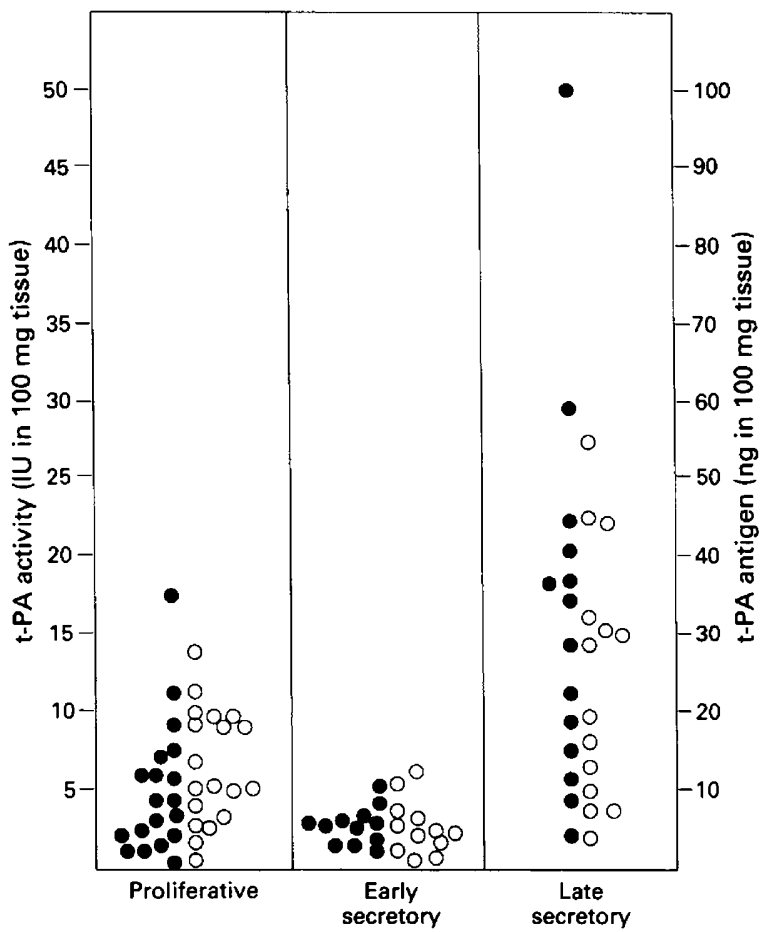

Fig. 1. Concentration of tissue plasminogen activator (t-PA) (O) activity and antigen $(O)$ in the human endometrium at proliferative $(n=19)$, early $(n=12)$, and late secretory $(n=14)$ phases of the menstrual cycle. 

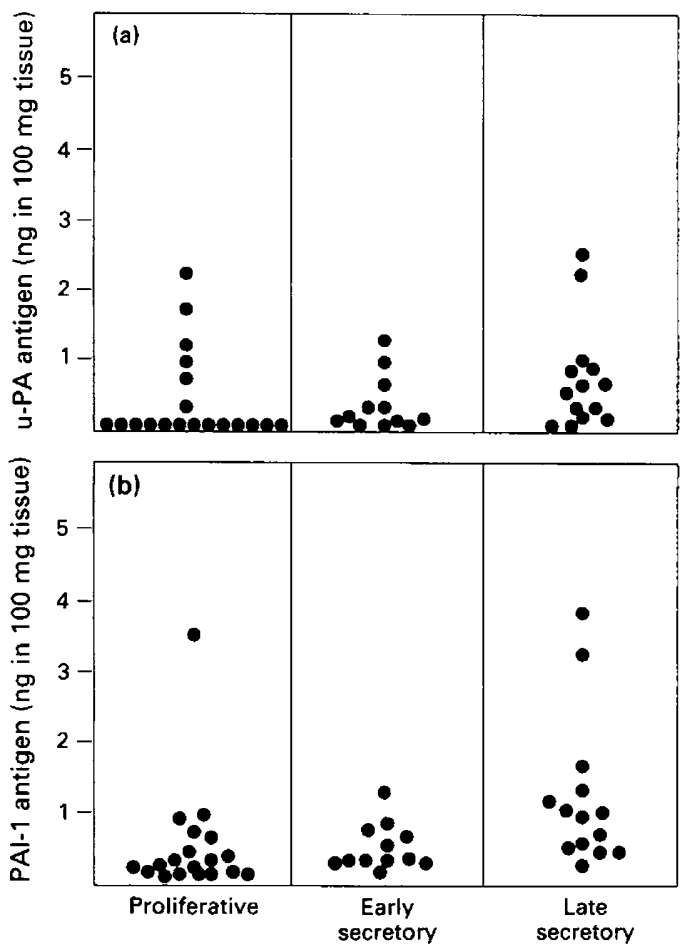

Fig. 2. Concentration of (a) urokinase plasminogen activator (u-PA) and (b) plasminogen activator inhibitor (PAI-1) antigen in the human endometrium at proliferative, early and late secretory phases of the menstrual cycle.

endometrium and uterine fluids. Oestrogen stimulates endometrial growth, and synthesis or release of PA. On the other hand, progesterone decreases the content and release of the activators. Inhibitors of PA have been known to reduce the menstrual blood loss (Mullins et al., 1980; Kneifel et al., 1982; Casslen et al., 1983a, b; Peltz et al., 1983).

In this study we observed that t-PA activity and antigen together with PAI-I antigen concentrations were significantly higher in late secretory endometrium than in either proliferative or early secretory endometrium. This observation of high fibrinolytic activity is similar to that reported by Casslen \& Astedt (1983b). t-PA activity and amounts of antigen were significantly higher in the proliferative than in early secretory endometrium. No significant differences were seen in amounts of PAI-1 antigen. PAI-1 activity could not be detected in the endometrium studied although low amounts of PAI-1 antigen were recorded. u-PA antigen concentrations tend to be high in the late secretory phase but the amount was not statistically different from the other two phases studied. Zymography studies demonstrated that both t-PA and u-PA are present in the endometrium at various phases of the menstrual cycle and they have also been detected using ELISA methods.

The physiological significance of PA in the endometrium is not clear. It would appear that in the luteal phase sex hormones could influence t-PA concentration in the endometrium. The increase in t-PA concentration in late secretory endometrium is also accompanied by an increase in amount of PAI-1 antigen when compared with proliferative and early secretory endometrium. No PAI-1 activity could be demonstrated in the phases of the endometrium studied which would suggest that t-PA activity is dominant in the endometrium. The low t-PA activity and amounts of antigen observed during the early secretory period could result from the release of t-PA into the uterine cavity. The low t-PA concentration seen in the early secretory phase may be essential for fertilization and for the attachment of the blastocyst to the endometrial surface for the nutrition 

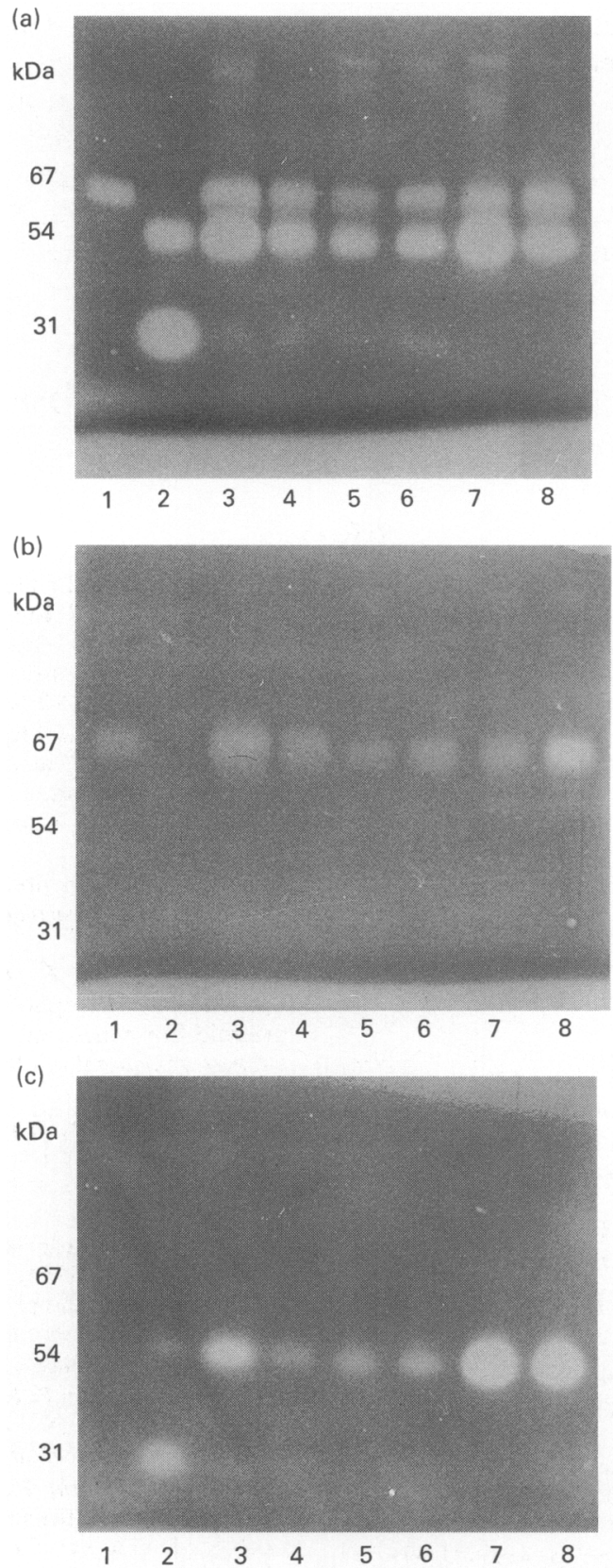

Fig. 3. Zymography studies and characterization of plasminogen activators (PAs) in the human endometrium. (a) Zymography studies. Lane 1: single chain t-PA $\left(1.0 \mathrm{iu} \mathrm{ml}^{-1}\right)$; Lane 2: two chain $\mathrm{u}-\mathrm{PA}\left(0.25 \mathrm{iu} \mathrm{m}^{-1}\right)$; and human endometrial extracts, Lanes 3 and 4 at proliferative, 5 and 6 early secretory, 7 and 8 late secretory phases. (b and c) Characterization using rabbit antibodies using the same samples as in (a), (b) anti-u-PA 1:100 dilution and (c) t-PA 1:50 dilution.

and survival of the pre-implantation blastocyst (Casslen \& Astedt, 1981) if conception occurs. Significant fibrinolytic changes seen in late secretory endometrium would favour an important biochemical step in the physiology of menstruation. 
In this study, significantly increased amounts of t-PA activity and antigen and PAI-1 antigen were found in the late secretory endometrium, whereas PAI-1 activity could not be detected and u-PA remained unchanged throughout the menstrual cycle. Leucocytes and macrophages are known to produce plasminogen activators and to increase in number during the pre-menstrual period (Unkeless et al., 1974; Granelli-Piperno et al., 1977). This factor may have contributed to the increase in t-PA concentrations in the late secretory endometrium. The cyclic variation of the sex hormone concentrations that is known to occur during the proliferative (oestrogenic) and secretory (progestational) stages of the menstrual cycle may also influence t-PA and PAI production.

The study was supported by the University Department of Obstetrics and Gynaecology Research Fund.

\section{References}

Astedt, B., Holmberg, L., Lecander, J. \& Thorell, J. (1981) Radioimmunoassay of urokinase for quantitation of plasminogen activators released in ovarian tumour cultures. European Journal of Cancer 17, 239-244.

Casslen, B. \& Astedt, B. (1981) Fibrinolytic activity of human uterine fluid. Acta Obstetrica et Gynecologica Scandinavia 60, 55-58.

Casslen, B. \& Astedt, B. (1983a) Reduced plasminogen activator content of the endometrium in oral contraceptive users. Contraception 28, 181-188.

Casslen, B. \& Astedt, B. (1983b) Occurrence of both urokinase and tissue plasminogen activator in the human endometrium. Contraception 28, 553-564.

Dano, K., Andreasen, P.A., Grondahl-Hansen, J., Kristensen, P., Nielsen, L.S. \& Skriver, L. (1985) Plasminogen activators, tissue degradation and cancer. Advances in Cancer Research 44, 139-266.

Granelli-Piperno, A. \& Reich, E. (1978) A study of proteases and protease inhibitor complexes in biological fluids. Journal of Experimental Medicine 148, 223-234.

Granelli-Piperno, A., Vasalli, J.D. \& Reich, E. (1977) Secretion of plasminogen activator by human polymorphonuclear leucocytes. Journal of Experimental Medicine 146, 1693-1706.

Kjaeldgaard, A., Ahlesteen, I., Larsson, B. \& Astedt, B. (1988) Progestogen regulation of tissue plasminogen activator in a human melanoma cell line. Thrombosis Research 49, 287-297.

Kneifel, M.A., Leytus, S.P., Fletcher, E., Weber, T., Mangel, W.F. \& Katzenellenbogen, B.S. (1982) Uterine plasminogen activator activity: modulation by steroid hormones. Endocrinology 111, 493-499.

Koh, S.C.L., Wong, P.C., Yuen, R., Chua, S.E., Ng, B.L. \& Ratnam, S.S. (1988) Plasminogen activators in the endometrium of subfertile women. Medical Science Research 16, 1111-1112.
Koh, S.C.L., Yuen, R., Viegas, O.A.C. Chua, S.E., Ng, B.L., Sen, D.K. \& Ratnam, S.S. (1989a) A plasmin generation method for the determination of tissue plasminogen activator (t-PA) activity in blood. Immunology and Cell Biology 67, 197-203.

Koh, S.C.L., Yuen, R., Viegas, O.A.C., Chua, S.E., Ng, B.L., Sen, D.K. \& Ratnam, S.S. (1989b) Plasma tissue plasminogen activator inhibitor (t-PAI) activity in normal subjects. Medical Science Research 17, 135-136.

Liedholm, P. (1975) On fibrinolysis in reproduction. Acta Obstetrica et Gynecologica Scandinavia Supplementum 41, 7-47.

Martin, O. \& Arias, F. (1982) Plasminogen activator production by trophoblast cells in vitro. Effect of steroid hormones and protein synthesis inhibitors. American Journal of Obstetrics and Gynecology 142, 402-409.

Mullins, D.E., Bazer, F.W. \& Roberts, R.M. (1980) Secretion of a progesterone-induced inhibitor of plasminogen activator by the porcine uterus. Cell 20, 865-872.

Peltz, S.W., Katzenellenbogen, S., Kneifel, M.A. \& Mangel, W.F. (1983) Plasminogen activators in tissues of the immature and oestrogen-stimulated rat uterus and in uterine luminal fluid: characterization and properties. Endocrinology 112, 890-897.

Unkeless, J.C., Gordon, S. \& Reich, E. (1974) Secretion of plasminogen activator by stimulated macrophages. Journal of Experimental Medicine 139, 834-850.

Weber, K. \& Osborn, M. (1969) The reliability of molecular weight determinations by dodecyl sulfatepolyacrylamide gel electrophoresis. Journal of Biological Chemistry 244, 44064412.

Revised manuscript received 20 January 1991 